\title{
Comparative Assessment on Machinability of Nano-Structured Bainitic Steel and Titanium64
}

\author{
Ashwin Polishetty ${ }^{1}$, Chinmay Sonavane ${ }^{2}$, Prasad Patil ${ }^{1}$, Guy Littlefair ${ }^{1}$ \\ ${ }^{1}$ Deakin University, Waurn Ponds, Victoria, Australia \\ ${ }^{2}$ Indian Institute of Technology, Madras, India \\ Email: ashwin.polishetty@deakin.edu.au
}

Received 11 April 2014; revised 10 May 2014; accepted 9 June 2014

Copyright @ 2014 by authors and Scientific Research Publishing Inc.

This work is licensed under the Creative Commons Attribution International License (CC BY). http://creativecommons.org/licenses/by/4.0/

c) (i) Open Access

\section{Abstract}

Titanium64 has characteristics well sought after for applications in demanding environments. In general, due to titanium64's high performance, it is a material which requires careful and well considered machining approaches in order to optimize the process. Nano-structured bainitic steel whilst having different application bases does none the less have similar machining and machinability short comes as that of titanium64. These similar characteristics have been compared and contrasted in this research study using parameters including cutting force, surface texture and metallography. The results tend to indicate that titanium64 has a poorer machinability characteristics compared to nano-structured bainitic steel. However, in terms of achieving greater surface texture characteristics, the nano-structured bainitic steel exhibited an enhanced capacity.

\section{Keywords}

Nano-Structured Bainitic Steel, Titanuim64, Machinability, Surface Roughness, Cutting Force

\section{Introduction}

Steel is defined as a Fe-Fe3C alloy containing varying amounts of carbon from $0.008 \%$ to $2.1 \%$ [1]. There are various phases present in steel depending on the iron-carbide equilibrium temperature. The variation of carbon concentrations and addition of alloying elements varies the material properties of steel drastically [2]. Nanostructured bainitic steel is one such type where alloy steel is heat treated, micro-structurally manipulated in order to obtain the desired material properties.

Nano-structured bainitic steel microstructure consists of bainitic ferrite in nano-dimensions and retained aus- 
tenite. It has an excellent combination of strength and ductility along with grain refinement. Nano-structured bainitic steel exhibits an elongation of 21\% for UTS above 2GPa [3]. The nano-structured bainitic steel used in this research is produced by austenitising steel at $900^{\circ} \mathrm{C}$ for 45 minutes, followed by isothermal holding the sample in a salt bath maintained at $200^{\circ} \mathrm{C}$ for 10 days [4].

Machinability of a material is defined as the ease with which the material is removed following less cutting force to obtain the desired surface finish [5]. The machinability of nano-structured bainitic steel and titanium64 has been evaluated using cutting and surface texture analysis.

Titanium is considered to be a super alloy because of its unique properties such has high strength to weight ratio, good resistance to corrosive environments and high load bearing capacity [6]. Typical engineering applications of titanium alloys include the manufacture of cryogenic devices and aerospace components. Some of the popular titanium alloys used in aerospace and medical implant industry are titanium64, commercially pure titanium, titanium5553 etc. This paper deals with titanium64 which consists of $6 \mathrm{wt} \%$ of aluminium and $4 \mathrm{wt} \%$ of vanadium. The microstructure of titanium64 is shown in Figure 1. Titanium exists in two crystallographic forms. At room temperature unalloyed titanium has a Hexagonal Close-Packed structure (HCP) crystal structure known as alpha $(\alpha)$-phase. At $883^{\circ} \mathrm{C}, \alpha$-phase transforms to a Body Centered Cubic (BCC) known as beta ( $\beta$ )-phase [7]. Titanium64 has been workhorse of the aerospace industry and probably $80 \%-90 \%$ of the titanium used on airframes has been this alloy. It is used in fuselage, nacelles, landing gear, wing and empennage.

Titanium has low thermal conductivity; hence the heat generated by the cutting action does not dissipate quickly. When machining any component, it is essential to satisfy surface integrity requirements. However, during machining and grinding operations, the surface of titanium alloys is easily damaged because of their poor machinability [6]. Near net shaping method is very difficult for most of the aerospace components due to complex physical shape, and high tolerance and good surface finish requirements [8]. Dandekar et al. carried out the hybrid machining assisted with laser [9]. In Laser Assisted Milling (LAM) workpiece material is heated and softened before entering cutting zone. Two to three folds of tool life improvements over conventional machining is achieved for hybrid machining up to the speed of $200 \mathrm{~m} / \mathrm{min}$ as reported by the author. Using the TiAlN coated tool in LAM and hybrid machining, 30\% to $40 \%$ of overall cost saving can be achieved [9]. Titanium alloys are generally difficult to machine at cutting speeds over $30 \mathrm{~m} / \mathrm{min}$, with HSS steel tools and $60 \mathrm{~m} / \mathrm{min}$ with cemented tungsten carbide tools. Other types of tool materials, including ceramic, diamond and cubic boron nitride are highly reactive with titanium alloys and as a consequence they are not used in the machining of these alloys [10]. Furthermore, chips weld easily on the tool to form build up edge (BUE) [11]. Both high helix angle and radial rake angles combine to create a higher effective rake or sheer plane [12].

High temperature strength, very low thermal conductivity, relatively low modulus of elasticity, high strain hardening, poor dislocation motion through the microstructure and high chemical reactivity play an important role in machining mechanism [13]. This research is an attempt to fill the existing gap with regards to the science of machining these material viz. nano-structured bainitic steel and titanium64 especially on the thermal behaviour of these materials in the cutting zone. This research deals with comparing the machinability characteristics of

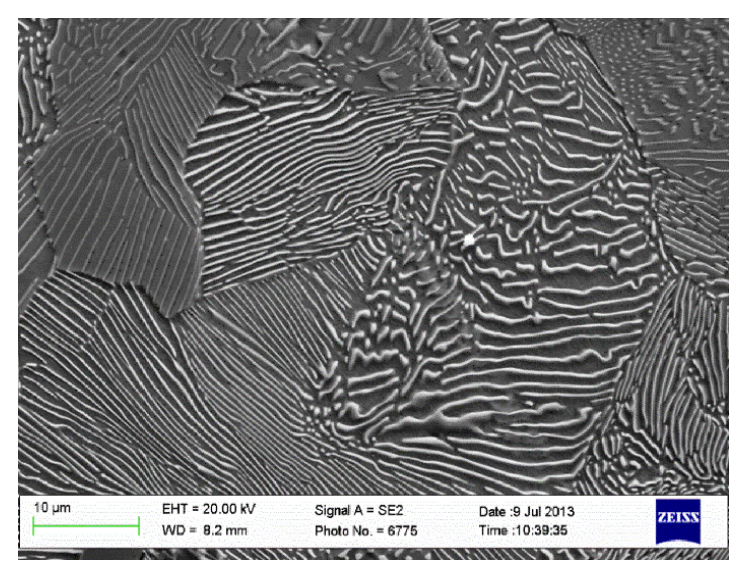

(a)

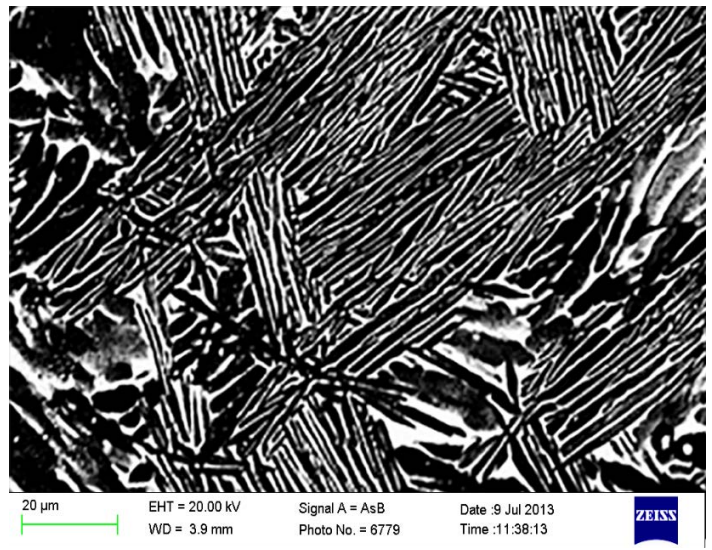

(b)

Figure 1. Microstructure of bulk material: (a) Nano-structured bainitic steel; (b) Titanium64. 
newly emerging materials; nano-structured bainitic steel and titanium64. As nano-structured bainitic steel being a relatively new material, very few research article exists on its machinability characteristics. Similar is the case with scarce amount of research data available on machining of titanium alloys. This paper attempts to provide data on machining performance and machinability of these materials.

\section{Experimental Design}

The experimental design for nano-structured bainitic steel and titanium64 consists of conducting milling trials at constant feed/tooth, $0.03 \mathrm{~mm} /$ tooth; machining speed- $100 \mathrm{~m} / \mathrm{min}$; coolant on/off and variable DoC- 1,2 and 3 $\mathrm{mm}$ followed by the surface roughness, metallography and the cutting force analyses (see Table 1 and Table 2). The cutting parameters were selected taking into consideration the cutting tool limitations and prior experience of the authors in carrying out experimentation on difficult to machine materials such as Austempered Ductile Iron (ADI). The varying coolant condition was selected in order to investigate the effect of thermal conductivity on the machining process. The efficiency of the coolant lies in successful dissipation of the heat generated and lubricating the cutting zone.

The variation in DoC was selected in order to investigate the effect of DoC on the surface texture of the machined sample. The cutting tool used was a $12 \mathrm{~mm}$ diameter solid carbide end mill and the machining trials were conducted on 5-axis machining center-Spinner MCV-2. The coolant used was a phenol-2.8\% which is mixed with water in ratio of 1:10. The description of trials with sample ID is given in Table 3 . The machined titanium64 block and nano-structured bainitic steel were subjected to surface texture analysis-roughness (Ra) using "Taylor Hobson-Form Talysurf". Stylus made up of diamond edge is used to determine the surface roughness. Data length used for testing was $15 \mathrm{~mm}$ and run-up length is $1 \mathrm{~mm} / \mathrm{sec}$. The cutting force analysis on the machined samples was carried out using a Kistler dynamometer-9257B. For metallographic analysis, the samples were mounted using polyfast material by the sintering process at $80^{\circ} \mathrm{C}$. An automatic polisher "Rotoforce 21 " was used for polishing of the samples. Supra-55VP SEM was used to characterize the samples and generate the microscopic images. The sample identification for nano-structured bainitic steel and titanium64 is shown in Table 3.

Table 1. Chemical composition of nano-structured bainitic steel.

\begin{tabular}{cccccccc}
\hline Element & $\mathrm{Fe}$ & $\mathrm{Si}$ & $\mathrm{Mn}$ & $\mathrm{C}$ & $\mathrm{Cr}$ & $\mathrm{Cu}$ & $\mathrm{Ni}$ \\
\hline Weight (\%) & 94.7 & 2.6 & 0.80 & 0.70 & 0.48 & 0.22 & 0.2 \\
\hline
\end{tabular}

Table 2. Chemical composition of titanium64.

\begin{tabular}{ccccccccc}
\hline Element & $\mathrm{V}$ & $\mathrm{Al}$ & $\mathrm{Sn}$ & $\mathrm{Zr}$ & $\mathrm{Mo}$ & $\mathrm{C}$ & $\mathrm{Si}$ & $\mathrm{Ti}$ \\
\hline Weight (\%) & 4.22 & 5.48 & 0.062 & 0.0028 & 0.005 & 0.36 & 0.022 \\
\hline
\end{tabular}

Table 3. Sample identity for nano-structured bainitic steel and titanium64.

\begin{tabular}{ccccc}
\hline sample ID & feed per tooth, $\mathrm{mm} /$ tooth & Cutting speed, $\mathrm{m} / \mathrm{min}$ & Depth of cut, $\mathrm{mm}$ & Coolant on/off \\
\hline 1 & 0.03 & 100 & 2 & Off \\
2 & 0.03 & 100 & 3 & Off \\
3 & 0.03 & 100 & 1 & On \\
4 & 0.03 & 100 & 2 & On \\
5 & 0.03 & 100 & 3 & On \\
\hline
\end{tabular}




\section{Results and Discussion}

Cutting forces measured during machining trials for nano-structured bainitic steel and titanium64 are analyzed, compared and discussed in this section. For milling, forces, Fx and Fy were considered to be the dominant compared to force in Fz, acting into the workpiece, normal to the surface. Cutting forces measured in the $\mathrm{x}$, $\mathrm{y}$ and z-directions for nano-structured bainitic steel and titanium64 are shown in Figure 2 and Figure 3 respectively. For both nano-structured bainitic steel and titanium64, cutting forces are comparatively higher for milling using coolant than without coolant.

This may be attributed to the harder microstructure with wet machining compared to the dry condition.T his can also be due to the denial of thermal softening effect on the workpiece by use of coolant. Therefore, reduction of cutting force in machining is required to acquire higher productivity and better machinability. Cutting force is higher in case of high cutting speed compared to low cutting speed. A general trend of cutting forces increasing with an increase in DoC was also observed. The higher strength of the workpiece material also contributes to higher cutting force. Due to the non-availability of tool wear measurements, an analogy could not be drawn between the higher cutting force and tool wear rate. Cutting force, Fx was the maximum force obtained and was picked to generate correlation graphs as shown in as shown in Figure 4 and Figure 5.

Surface roughness $(\mathrm{Ra})$ measurement for nano-structured bainitic steel and titanium64 was done and a correlation was established with the cutting forces as shown in Figure 4 and Figure 5. The difference in thermal conductivity of nano-structured bainitic steel and titanium64, especially the way heat is dissipated out of the cutting zone plays an important role in determining the surface roughness of the machines surface. For nano-structured bainitic steel, the surface roughness is higher for dry machining than wet machining and vice-versa for titanium64.

For nano-structured bainitic steel, as the DoC increases surface roughness remain constantly low initially and increases for $3 \mathrm{~mm}$ DoC for both dry and wet machining. For titanium64, a completely different trend was observed may be attributed to the poor thermal conductivity of titanium 64. Chemical affinity of titanium alloy to the tool was seen more when machining in dry condition. This was reduced in case of wet machining, as the coolant prevents such reaction at the tool-workpiece interface. This can also be explained as that the specific cutting force needed to machine the material is more when cutting speed is high. The use of coolant in machining reduces the tool-workpiece temperature and produces a lower surface roughness in materials having better thermal conductivity like nano-structured bainitic steel.

A microstructural comparison of the machined surface of nano-structured bainitic steel and titanium64 is shown in Figure 6. On observing the microstructure of machined nano-structured bainitic steel, the breaking of the long ferrite laths and exposing the austenite for a likely phase transformation reaction was presumed.

When examining the microstructure of the machined Ti-6Al-4V alloy under SEM, phase transformation in the microstructure is likely visible when compared with the original SEM microstructure. Lamellar type light colored $\alpha$-phase was seen with dark colored $\beta$-phase in between in SEM microstructure. This showed that the alloy has been likely tempered which resulted in lamellar like $\beta$-phase microstructure.

\section{Conclusion}

This paper on comparative assessment of machinability of nano-structured bainitic steel and titanium64, assisted

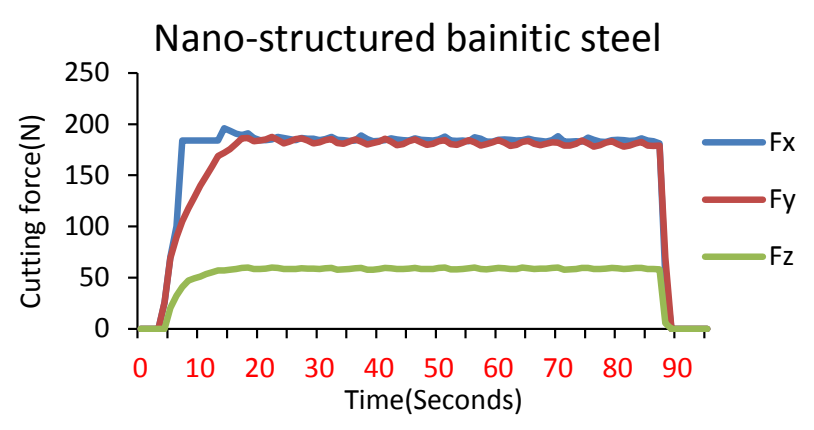

Figure 2. Nano-structured bainitic steel cutting force measurements along $\mathrm{x}, \mathrm{y}$ and $\mathrm{z}$ direction for dry machining at 100 $\mathrm{m} / \mathrm{min}$ and DoC-2 $\mathrm{mm}$. 


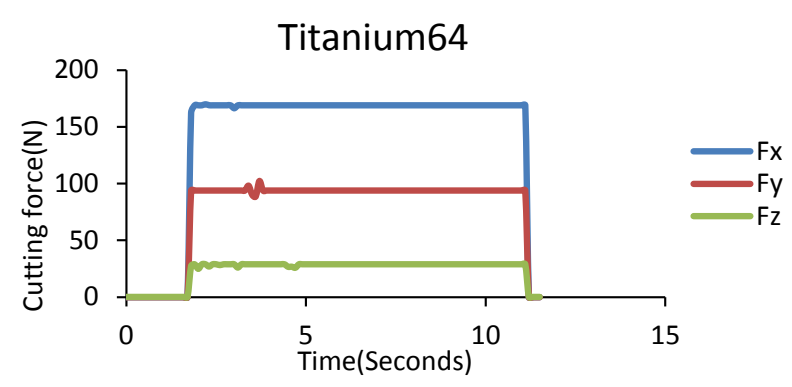

Figure 3. Titanium64 cutting force measurements along $\mathrm{x}, \mathrm{y}$ and $\mathrm{z}$ direction for dry machining at $100 \mathrm{~m} / \mathrm{min}$ and DoC-2 $\mathrm{mm}$.

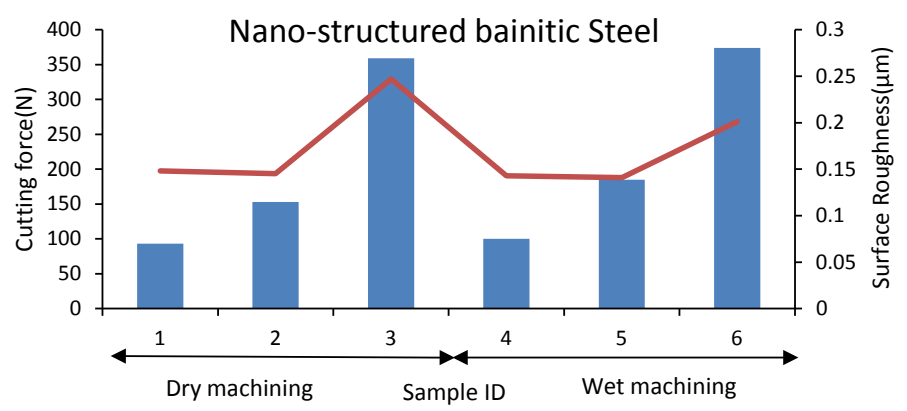

Cutting force $\longrightarrow$ Surface roughness

Figure 4. Correlation between cutting force and surface roughness for machining of nano-structured bainitic steel.

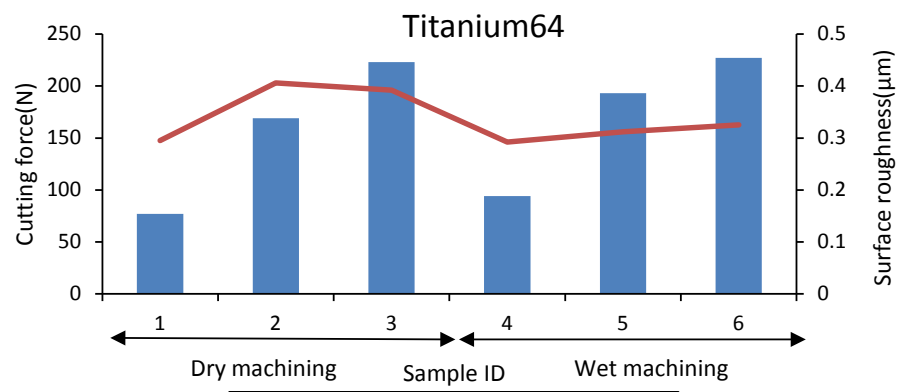

Cutting force $\longrightarrow$ Surface roughness

Figure 5. Correlation between cutting force and surface roughness for machining of titanium64.

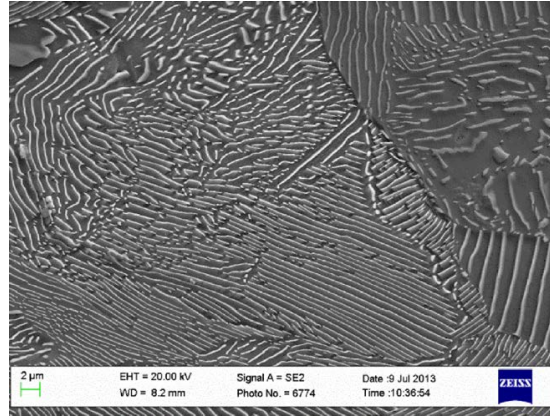

(a)

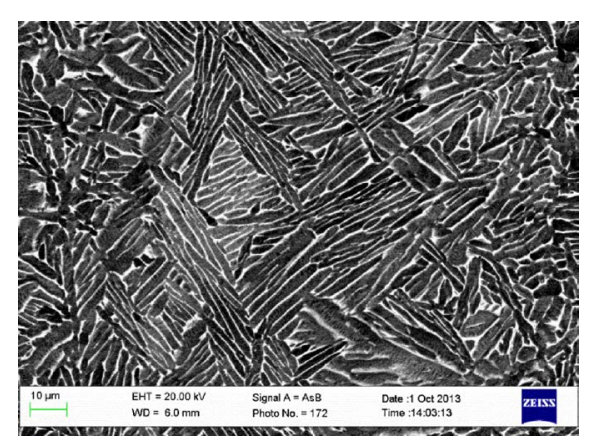

(b)

Figure 6. Microstructure of machined surface: (a) Nano-structured bainitic steel; (b) Titanium64. 
in providing an insight into the machining behaviour of these materials. The efficiency of the coolant in dissipating heat and lubricating the cutting zone, and significance of thermal conductivity of the workpiece material were clearly evident for both materials, as the cutting forces were comparatively higher for milling using coolant than that without coolant. This can also be due to the denial of thermal softening effect on the workpiece by use of coolant. Correlation was established between the cutting force and the surface roughness for both materials. For nano-structured bainitic steel, the surface roughness is higher for dry machining than wet machining and vice-versa for titanium64. On microstructural examination of machined surface of the materials, a common observation is the displacement/disintegrating of grains and likely extent of microstructural phase change leading to further hardening of the material.

\section{References}

[1] Porter, D.A., Easterling, K.E. and Sherif, M. (2009) Phase Transformations in Metals and Alloys, Third Edition, CRC Press, Boca Raton.

[2] Abbaschian, R. and Red-Hill, R.E. (2009) Physical Metallurgy Principles, Cengage Learning, Stamford.

[3] Caballero, F. and Bhadeshia, H. (2004) Very Strong Bainite. Current Opinion in Solid State and Materials Science, 8, 251-257. http://dx.doi.org/10.1016/j.cossms.2004.09.005

[4] Beladi, H., et al. (2012) Characterization of Nao-Structured Bainitic Steel. International Journal of Modern Physics, 5, $1-5$.

[5] Sandvik Coromant (1994) Modern Metal Cutting. Sandviken Sweden: A B Sandviken Coromant.

[6] Che-Haron, C.H. and Jawaid, A. (2005) The Effect of Machining on Surface Integrity of Titanium Alloy Ti-6\% Al4\% V. Journal of Materials Processing Technology, 166, 188-192.

http://dx.doi.org/10.1016/j.jmatprotec.2004.08.012

[7] Henriques, V.A.R., de Campos, P.P., Cairo, C.A.A., et al. (2005) Production of Titanium Alloys for Advanced Aerospace Systems by Powder Metallurgy. Materials Research, 8, 443-446. http://dx.doi.org/10.1590/S1516-14392005000400015

[8] Krebs, R.E. (2006) The History and Use of Our Earth’s Chemical Elements: A Reference Guide. Greenwood Publishing Group, Westport, 90.

[9] Chinmaya, J.B., Dandekar, R. and Shin, Y.C. (2009) Machinability Improvement of Titanium Alloy (Ti-6Al-4V) via LAM and Hybrid Machining. International Journal of Machine Tools and Manufacture, 10, 174-182.

[10] Noland, D., et al. (2001) High Performance Milling in Aerospace Materials. Niagara Cutters, 1, 1-10.

[11] López de lacalle, L.N., Pérez, J., Llorente, J.I. and Sánchez, J.A. (2000) Advanced Cutting Conditions for the Milling of Aeronautical Alloys. Journal of Materials Processing Technology, 100, 1-11.

[12] Lei, S. and Liu, W. (2002) High-Speed Machining of Titanium Alloys Using the Driven Rotary Tool. International Journal of Machine Tools and Manufacture, 42, 653-661. http://dx.doi.org/10.1016/S0890-6955(02)00012-3

[13] Boyer, R. (1996) An Overview on the Use of Titanium in the Aerospace Industry. Materials Science and Engineering: A, 213, 103-114. http://dx.doi.org/10.1016/0921-5093(96)10233-1 
Scientific Research Publishing (SCIRP) is one of the largest Open Access journal publishers. It is currently publishing more than 200 open access, online, peer-reviewed journals covering a wide range of academic disciplines. SCIRP serves the worldwide academic communities and contributes to the progress and application of science with its publication.

Other selected journals from SCIRP are listed as below. Submit your manuscript to us via either submit@scirp.org or Online Submission Portal.
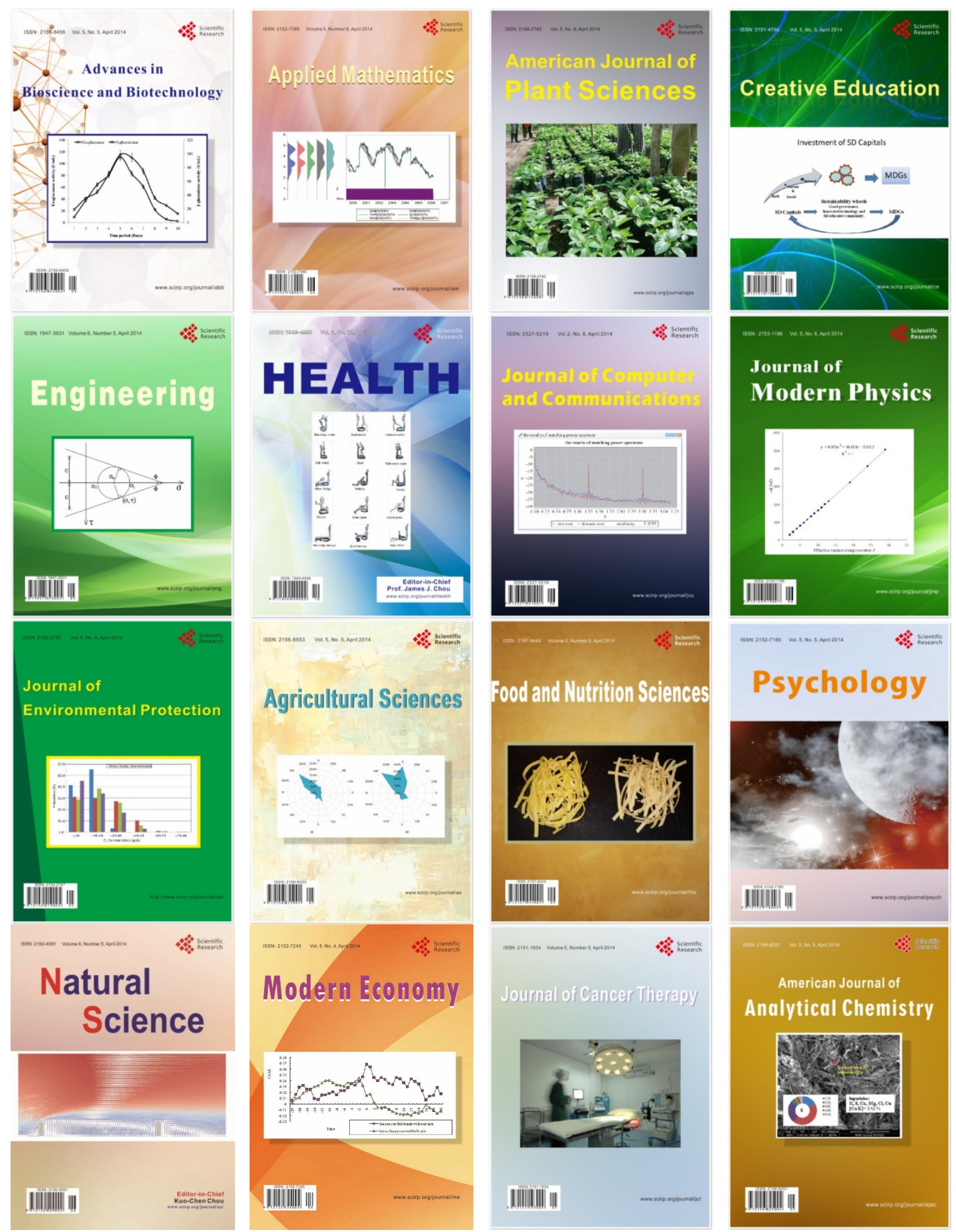